\title{
Novel Sources of Fetal Stem Cells for Future Regenerative Medicine
}

\author{
Yani Lina ${ }^{1,2 *}$ and Andi Wijaya ${ }^{1,3}$ \\ ${ }^{1}$ Post Graduate Program in Clinical Biochemistry, Hasanuddin University, Jl. Perintis Kemerdekaan Km.10. Makassar, Indonesia \\ ${ }^{2}$ Prodia Stemcell Indonesia, Jl. Kramat VII No.7, Jakarta, Indonesia \\ ${ }^{3}$ Prodia Clinical Laboratory, Jl. Cisangkuy No.2, Bandung, Indonesia \\ ${ }^{*}$ Correspondence: yani_lina1979@yahoo.com
}

\section{Abstract}

Mesenchymal stromal cells are multipotent cells considered to be of great promise for use in regenerative medicine. However, the cell dose may be a critical factor in many clinical conditions and the yield resulting from the ex vivo expansion of mesenchymal stromal cells derived from bone marrow may be insufficient. Thus, alternative sources of mesenchymal stromal cells need to be explored.

There are multiple extra-embryonic tissues emerging during gestation including umbilical cord blood (UCB), amniotic fluid (AF), Wharton's jelly, the amniotic membrane and the placenta, which are all discarded following birth. Fetal stem cells from these sources actually represent a new class of stem cells developmentally and operationally located between the state of embryonic stem cells and adult stem cells, sharing and exhibiting features of pluripotency and multipotency, without necessarily implying that they can generate every type of tissue.

Fetal stem cells have been recently isolated from several tissues (amniotic fluid, umbilical cord, Wharton's jelly, amnion and placenta). They are derived either from the fetus proper or from the supportive extra-embryonic structures. They represent ideal sources for regenerative medicine since they are easily accessible, exhibit high proliferation rates, do not form teratomas and present no ethical reservations like embryonic stem cells (ESC). Their functional features indicate that they actually represent intermediates between ESC and adult stem cells.

KEYWORDS: Mesenchymal stem cells, fetal stem cells, amniotic fluid, umbilical cord, placenta, Wharton's jelly

Indones Biomed J 2012; 4 (1): 3-11

\section{Introduction}

Mesenchymal stem cells (MSC) are a prototypical adult stem cell with capacity for self-renewal and differentiation with a broad tissue distribution (1). In 1970, Friedenstein and colleagues demonstrated that bone marrow (BM) contained a population of hematopoietic stem cells (HSC) and a rare population of plastic-adherent stromal cells. These plastic adherent cells, initially referred to as stromal cells, is now commonly called MSC (2). Friedenstein was the first investigator to demonstrate the ability of MSC to differentiate into mesoderm-derived tissue and to identify their importance in controlling the hematopoietic niche (3). In 1980, MSC were shown to differentiate into osteoblasts, chrondrocytes, and adipocytes (4-5). Caplan demonstrated that bone and cartilage turnover was mediated by MSC, and the surrounding conditions were critical to inducing MSC differentiation (6). In late 1990, Kopen et al. described the capacity of MSC to transdifferentiate into 
ectoderm-derived tissue (7). MSC were demonstrated to suppress T-lymphocyte proliferation, which paved the way to the application of MSC therapy for allogeneic transplantation and to its potential in immunomodulatory therapy (8). They offer the advantage that they are easily expanded and stored ex vivo and are considered to be "immunoprivileged". Thus, once harvested, they can safely be infused into either autologous or allogenous hosts owing to their lack of host immune reactivity (9-12). From a therapeutic perspective, and facilitated by the ease of preparation and immunologic privilege, MSC are emerging as an extremely promising therapeutic agent for tissue regeneration (1).

MSC represent a rare population (approximately $0.001-0.01 \%$ nucleated cells) of adult human bone marrow cells, but they can also be identified in other adult tissues such as muscle, periosteum, adipose and other connective tissues (13-16). Large numbers of MSC would be needed for regenerative medicine but the frequency and expansion capacity of adult MSC are limited and may decrease with age. Thus, alternative sources of MSC need to be explored (17). The recent isolation of fetal stem cells from several sources either at the early stages of development or during the later trimesters of gestation, sharing similar growth kinetics and expressing pluripotency markers, provides strong support to the notion that these cells may be biologically closer to the embryonic stem cells, actually representing intermediates between embryonic stem cells and adult mesenchymal stem cells, regarding proliferation rates and plasticity features, and thus able to confer an advantage over postnatal .

\section{Novel Sources of Fetal Stem Cells}

Human MSC have been isolated from bone marrow, adipose tissues, cord blood, amniotic fluid, amniotic membrane, placenta, and umbilical cord tissues (19-30). Bone marrow (BM) has been considered the main MSC source because of their potential to both proliferate and differentiate. However, other sources of similar cell populations are being investigated, because BM-derived MSC isolation requires a painful and invasive procedure, the frequency of MSC is low, and their ability to proliferate and differentiate declines with age (19,31-33).

Adipose tissue has recently been identified as a convenient alternative source of MSC-like cells. Adipose tissue-derived stem cells (ADSC) are available in quantities of hundreds of million cells per individual, have an extensive self-renewal capacity, are easily isolated by differential sedimentation, and can be cultured for several months in vitro with low level of senescence. ADSC also have the potential to differentiate into various cells, including adipocytes, osteoblasts, chondrocytes, neurons, and multinucleated myocytes in response to lineagespecific induction factors $(14,34-40)$.

Mesenchymal stromal cells from amniotic fluid represent a relatively homogenous population of immature cells with immunosuppressive properties and extensive proliferative potential. Despite their high proliferative capacity in culture, studies have not observed any karyotypic abnormalities or transformation potential in vitro nor any tumorigenic effect in vivo (41).

Umbilical cord blood (UCB) is an easily accessible alternative source for multipotent MSC and is generally believed to provide MSC with a higher proliferative potential compared with adult bone marrow. However, reaching the estimated clinical dose of at least $2 \times 10^{6} \mathrm{MSC}$ per kilogram body weight of adult patients has been a major problem that has hampered the progress of clinical UCB MSC applications (42). Umbilical cord and amniotic membrane are attractive sources to obtain adult stem cells due to total global abundances, ease in culture, and fewer ethical concerns unlike those of embryonic stem cells. Isolated stem cells can still differentiate into many different lineages. Hence, the use of umbilical cord and amniotic membrane as sources of stem cells could be one of the answers to the upcoming application of stem cells in regenerative medicine (43).

Placental tissue draws great interest as a source of cells for regenerative medicine because of the phenotypic plasticity of many of the cell types isolated from this tissue. Furthermore, placenta, which is involved in maintaining fetal tolerance, contains cells that display immunomodulatory properties. These two features could prove useful for future cell therapy-based clinical applications. Placental tissue is readily available and easily procured without invasive procedures, and its use does not elicit ethical issue (44). More recently, some groups have reported success in isolating and establishing MSC cultures from umbilical cord (UC) vein and UC stroma, also called Wharton's jelly (45-49).

Fetal stem cells represent a relative newcomer in the field, exhibiting unique and fascinating features, while recent studies have so far provided an impressive wealth of information and new insight into our understanding of the biology of stem cells in general and have suggested putative strategies to exploit their therapeutic potential. These cells can be derived either from the fetus proper or from the supportive extra-embryonic structures that are of 


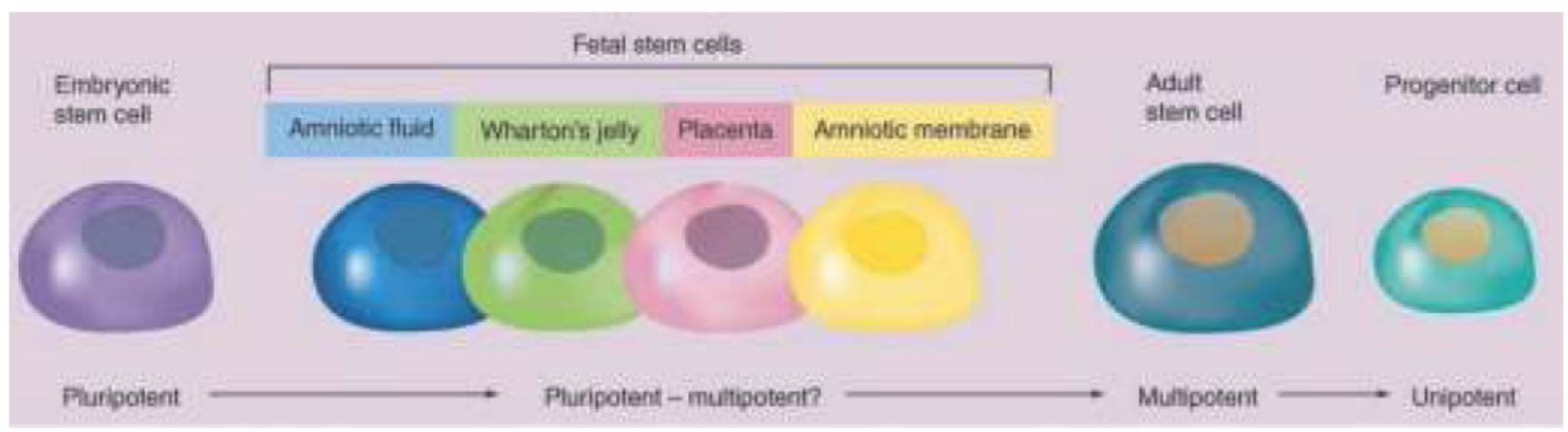

Figure 1. Current Model for the Developmental Position and Potency of the Fetal Stem Cells from Several Fetal Sources Emerging During Gestation, Such As the Amniotic Fluid, Wharton's Jelly, Placenta and Amniotic Membrane (Used with permission from American Society of Hematology. 2009).

fetal origin (50). A series of recent studies regarding the numerous novel features of fetal stem cells have reignited our interest in the field of stem-cell biology and in the possibilities for the eventual repair of damaged organs and the generation of in vitro tissues on biomimetic scaffolds for transplantation. These studies, employing elegant approaches and novel technologies, have provided new insight regarding the nature and the potential of fetal stem cells (18).

\section{Amniotic Fluid Stem Cells}

Traditionally, amniotic fluid (AF), via amniocentesis, has been used for decades as a consistent source for prenatal diagnosis; however, recent studies have provided important clue about the potential of AF cells to become an alternative source of stem cells (23-24,51-59). The cells are mostly of epithelial nature, derived either from the developing fetus or from the inner surface of the amniotic membrane. AF cells of earlier gestational age seem to express higher levels of endoderm and mesoderm markers compared with those of later gestational age, while ectodermal markers show no difference (57).

Human amniotic fluid has great cellular heterogeneity, the composition of which varies with gestational age and fetal development. The viable adherent cells of amniotic fluid can be classified into three large groups according to their morphologic and biologic characteristics: epitheloid (E-type) cells, with a low expansion potential; typical amniotic fluid (AF-type) cells, with a moderate expansion potential; and fibroblastoid (F-type) cells, with an enormous expansion potential. Human amniotic fluid- derived mesenchymal stromal cells (hAMSC) possess the potential to be used in regenerative medicine, given their great expansion capacity, differentiation potential and probably great undifferentiation $(51,53,55,60-76)$. Recent study by Miranda-Sayago et al. showed that F-type hAMSC exhibit reproducible biologic characteristics, confirming that these cells are ideal candidates for use in regenerative medicine (77).

Systematic studies on the yield of AF-MSC have disclosed that these cells proliferate rapidly greater than ninefold logarithmic cell expansion within a mean period of 32.9 days, regardless of the serum type or the gestational age. This implies that as little as $5 \mathrm{~mL}$ of AF can readily produce more than $100 \times 10^{6}$ cells required to engineer a surgically implantable construct (59). The in vivo applications of AF-MSC are still at an early stage (18). Amniotic fluid stem (AFS) cells might represent a novel source for cell therapy and cell transplantation strategies in repair following ischemic heart disease, with a possible paracrine mechanism of action and a potential molecular candidate for acute cardioprotection (75).

Recent studies support cell-based therapies for cancer treatment. An advantageous cell types for such therapeutic schemes are the mesenchymal stem cells (MSC) that can be easily propagated in culture, genetically modified to express therapeutic proteins, and exhibit an innate tropism to solid tumors in vivo. The AF-MSC tropism and capability to transport interferon beta (IFN $\beta$ ) to the region of neoplasia in a bladder tumor. Study showed significant inhibition of tumor growth as well as prolonged survival of mice were observed in the presence of IFN $\beta$-AF-MSC. Collectively, these results document the great potential of AF-MSC as anti-cancer vehicles, implemented by the targeting of the tumor site and further facilitated by their high proliferation rate and expansion efficiency in culture (76). 


\section{Umbilical Cord Blood Stem Cells}

During the last 23 years, umbilical cord blood (UCB) has been exploited as a rich source of hematopoietic and progenitor stem cells to establish therapeutically effective hemopoiesis, both for malignant and non-malignant disorders (77). Approximately $1 \%$ of the mononuclear cord blood cells express the CD34 antigen, which represents the cardinal marker for hematopoietic stem cells (HSC). The capacity of $\mathrm{CD} 34^{+}$stem cells for selfrenewal and differentiation to several cell lineages has been convincingly established by employing a series of in vitro and in vivo assays $(18,77)$.

UCB-MSC, representing the second major cell population of cord blood, are unique since they possess an intermediate phenotype that more closely resembles embryonic stem cells (ESC). Beside the typical markers for MSC (i.e SH2 or CD105, SH3 or CD73 and CD44), UCB-MSC also express markers for ESC such as Oct-4 that is essential for inhibiting tissue-specific genes and thus enhancing self-renewal and pluripotency. Further studies have extended the embryonic profile of the UCBMSC by documenting significant expression of additional ESC markers including SSEA-3, SSEA-4, Tra 1-60, Tra 1-81 and Nanog. Furthermore, their multipotency and differentiation capacity to cell lineages derived from all three germ layers has been documented (77-83).

UCB MSC with retained differentiation potential can be expanded to a clinical quantity of more than $1 \times 10^{8}$ cells with approximately 7 weeks. The rapid generation of large quantities of MSC from human UCB may ease the analysis of the biology and function of UCB MSC in various experimental models (42).

\section{Wharton's Jelly Stem Cells}

The umbilical cord connects the fetus to the placenta. In addition to its essential role in prenatal development, the human umbilical cord has now been recognized as an ethically acceptable, safe and sustainable source of stem cells $(49,85)$. The umbilical cord contains one vein and two arteries which are surrounded by mucoid connective tissue, and this is called the Wharton's jelly. The cord is covered by an epithelium derived from the enveloping amnion. The network of glycoprotein microfibrils and collagen fibrils in the Wharton's jelly has been previously studied. In the Wharton's jelly, the most abundant glycosaminoglycan is hyaluronic acid which forms a hydrated gel around the fibroblasts and collagen fibrils and maintains the tissue architecture of the umbilical cord by protecting it from pressure. The phenotypic stromal cells in the Wharton's jelly are fibroblast-like cells. Mesenchymal cells isolated from the umbilical cord express matrix receptors (CD44, CD105) and integrin markers (CD29, CD51), but not hematopoietic lineage markers (CD34, CD45). Interestingly, these cells also express significant amounts of mesenchymal stem cell markers (SH2, SH3) (86-89).

Technical procedures to isolate MSC from the Wharton's jelly are poorly investigated and vary dramatically depending on the authors. Although the enzymatic treatment with collagenase is the most widely used technique for isolating stromal cells, this treatment varies in the literature. Trypsin or other enzymes such as hyaluronidase have been frequently but not systematically added to the collagenase, and the incubation time also varies from 4 to $>24$ hours. Moreover, some authors have removed the cord vessels by stripping them manually before enzymatic treatment. Recently, a simplified protocol based uniquely on the capacities of MSC to adhere to a plastic surface without enzymatic treatment or dissection. Using this method, MSC can be isolated from all human umbilical cords and obtain a mean of $1.4 \times 10^{8}$ cells at the second passage and $>7 \times 10^{9}$ cells at the third. The expanded cells express characteristic markers and presented typical functional properties of MSC such as differentiation capacities, immunologic properties, and hematopoietic supportive functions $(45,48,90-94)$.

Compared to BM-MSC, Wharthon's Jelly-MSC had higher expression of undifferentiated human embryonic stem cell (hES) markers like NANOG, DNMT3B, and GABRB3, pluripotent/stem cell markers, as well as some early endodermal markers both at early and late passages. Wharton's Jelly-MSC possess properties of true stem cells, which they retain even after extended in vitro culture (93). Since Wharton's jelly cells (WJC) expand faster and to a greater extent than adult-derived MSC, these finding suggest that WJC are a primitive stromal cell population with therapeutic potential. The preclinical work suggests that the WJC are therapeutic via trophic rescue and immune modulation (95). Several attempts have been initiated recently regarding the in vivo assessment of differentiated cells derived from Wharton's jelly MSC as a basis for cell therapy. Enhanced muscle regeneration has recently been documented following transplantation of umbilical cord matrix stem cell (UCMSC) in a mouse model of severe muscle damage (96). 
Human UCMSC may have the ability to differentiate along several cell lineages of mesodermal or ectodermal origin $(45,95,97-100)$. Furthermore, recent studies reported that hUCMSC were able to differentiate both in vivo and in vitro into hepatocyte-like cells and pancreatic islet precursors of endodermal origin $(95,101)$. Exposed to a hepatogenic culture medium, hUCMSC expressed hepatic markers including albumin, $\alpha$-fetoprotein, cytokeratin- 19 , connexin-32 and dipeptidyl peptidase IV (95). This study provided the foundation for the application of hUCMSC for liver regeneration. Like other MSC, hUCMSC are able to differentiate along a chondrogenic lineage under the stimulation of TGF- $\beta$ in 3D cell pellets and polyglygolic acid (PGA) scaffolds $(45,89,102-104)$. A further modified chondrogenic environment, perhaps including the investigation of factors such as bioactive chemical signals (e.g. growth factors and aggrecan), oxygen tension, coculture, mechanical stimulation and/or in vivo regulation, will be needed to enhance chondrogenesis to apply hUCMSC in hyaline cartilage tissue engineering (105).

hUCMSC can differentiate into neuron-like cells when cultured with neuronal-conditioned medium (NCM) for 6 days (106). Moreover, transplantation of dopaminergic neurons derived from hUCMSC into the striatum of parkinsonian rats alleviates lesion-induced, amphetamineevoked rotation behavior (107). The therapeutic benefits of hUCMSC transplantation for ischemic stroke are likely due to the ability of the cell to produce growth-promoting factors. Thus, hUCMSC transplantation may be an effective therapy in the future (108).

\section{Amniotic Membrane Stem Cells}

Amniotic membrane, or amnion, has recently emerged as another novel and alternative fetal source of stem cell population. Specifically, amniotic membrane, lacking any vasculature, is derived from the epiblast by day 8 , comprising three layers. The three layers are an inner epithelial layer consisting of epithelial cells termed amniotic epithelial cells (AEC), an intermediate basement membrane lacking any cellular component and an outer layer juxtaposed to the chorion consisting of mesenchymal stem cells calles amniotic mesenchymal or amniotic membrane mesenchymal stromal cells (AM-MSC). Since these amnion cells, often called amnion-derived stem cells, originate from epiblast cells, it is conceivable that they might retain, and eventually portray, several stem cell features through gestation and are associated with a low percentage of HLA antigen-expressing cells (18).

Unlike other mesenchymal cells, only human amniotic membrane-derived mesenchymal stem cells (hAMS) express no major histocompatibility complex (MHC) class I molecule and may be expected to show immunologic tolerance. Because hAMC have a high ability to transdifferentiate into cardiomyocyte and to acquire immunologic tolerance in vivo, they can be a promising cellular source for allograftable stem cells for cardiac regenerative medicine (109).

The plasticity of amnion-derived stem cells has also been recently tested in cultures at the clonal level, where long-term self-renewal and multidifferentiation capacity have been documented (110). The proliferation rate of AM-MSC was found to lead to an approximately 300 -fold expansion in 21 days, yielding $2.9 \times 10^{6}$ cells (111).

\section{Placenta-Derived Stem Cells}

As a unique and transient fetomaternal organ, the placenta represents a significant, valuable and promising source of stem cells with variable potency (18). The placenta is a fetomaternal organ consisting of 2 components: the maternal component, termed the deciduas, originating from the endometrium; and the fetal component, including the fetal membranes-amnion and chorion-as well as the chorionic plate, from which chorionic villi extend and make intimate contact with the uterine decidua during pregnancy (112). The pure stem cells populations derived from human placental tissues are the chorionic mesenchymal stromal cells and the chorionic trophoblastic cells, both demonstrating variable plasticity $(44,50)$.

International Workshop on Placenta-Derived Stem Cells saw the following nomenclature proposed: human amniotic epithelial cells (hAEC), human amniotic mesenchymal stromal cells (hAMSC), human chorionic mesenchymal stromal cells (hCMSC), and human chorionic trophoblastic cells (hCTC). Furthermore, isolation protocols, phenotypic markers, and in vitro differentiation potential have been described for hAEC, hAMSC and hCMSC (44).

The placental tissues harbor different cell types that may complement each other in a clinical setting (i.e amniotic epithelial cells of early embryological origin with multilineage differentiation potential, as well as cells with immunomodulatory properties (44). It is tempting to speculate that placenta-derived cells may also be preferable 
from an immunological point of view, given the unique role of this tissue in maintaining fetomaternal tolerance throughout pregnancy, and supported by the finding that placental cells show a greater capacity to down-regulate T-cell proliferation in vitro compared to bone marrowderived cells (112).

The large number of hepatic genes and functions identified in human amniotic epithelium (hAE) suggest that if effective and efficient methods were developed to induce complete hepatic differentiation, hAE could be a useful source of cells for transplant procedures. Preclinical investigations with hepatic differentiation of hAEC have been promising (44). Human AEC have shown particular potential for treating central nervous system disorders. Since the discovery that hAEC have stem cell properties, express neural and glial markers and neural specific proteins, and also have the capacity to produce and secrete neurotransmitters, cell therapy with these cells has been considered (113-116). Successful transplants of hAEC into caudate nucleus, hippocampus and spinal cord have been reported (117-121). Transplantation of hAEC in a rat model of Parkinson's disease reversed the condition and prevented neuronal death (117-118).

hAEC transplants produce beneficial results in animal models of spinal cord injury. They were found to exhibit neuroprotection in acute phases of injury and facilitate regeneration of long tracts in long-term phases of recovery, as measured by behavioral assessment. The beneficial effect may be mediated through the secretion of novel neurotrophic factors. The preclinical studies reported strongly support the hypothesis that placenta hold much promise for the development of cell-based therapies for clinical application in the near future (44).

\section{Summary}

Recent studies on the various types of fetal stem cells have suggested that they represent a new class of stem cells developmentally and operationally located between the state of ESC and adult stem cells, sharing and exhibiting features of pluripotency and multipotency, without implying that they can generate every tissue. Stem cells derived from these fetal extra-embryonic sources, mostly of the mesenchymal type, have the advantage that they rapidly expand to adequate numbers required for clinical applications, and display negligible immunogenicity and demonstrate no evidence for teratoma formation, while presenting no ethical concerns. The fascinating features and the potential therapeutic properties of fetal stem cells from the various fetal sources described here are expected to be gradually implemented at the clinical level, through the establishment of comprehensive international guidelines for the clinical translation of stem cells and their direct derivatives $(18,122)$.

\section{References:}

1. Williams AR, Hare JM. Mesenchymal Stem Cells: Biology, Pathophysiology, Translational Findings, and Therapeutic Implications for Cardiac Disease. Circ Res 2011; 109: 92340.

2. Friedenstein AJ, Chailakhjan RK, Lalykina KS. The Development of Fibroblast Colonies in Monolayer Cultures of Guinea-Pig Bone Marrow and Spleen Cells. Cell Tissue Kinet 1970; 3: 393-403.

3. Friedenstein AJ, Chailakhyan RK, Latsinik NV, Panasyuk AF, Keiliss-Borok IV. Stromal Cells Responsible for Transferring the Microenvironment of the Hematopoietic Tissues: Cloning In Vitro and Retransplantation In Vivo. Transplantation 1974; 17: 331-40.

4. Piersma AH, Brockbank KG, Ploemacher RE, van Vliet E, Brakelvan Peer KM, Visser PJ. Characterization of Fibroblastic Stromal Cells from Murine Bone Marrow. Exp Hematol 1985; 13: 237-43.

5. Caplan Al. Molecular and Cellular Differentiation of Muscle, Cartilage, and Bone in the Developing Limb. Prog Clin Biol Res 1986; 217B: 307-18.

6. Caplan Al. Mesenchymal Stem Cells. J Orthop Res 1991; 9: 641-50.

7. Kopen GC, Prockop DJ, Phinney DG. Marrow Stromal Cells Migrate Throughout Forebrain and Cerebellum, and They Differentiate into Astrocytes After Injection Into Neonatal Mouse Brain. Proc Natl Acad Sci USA 1999; 96: 10711-6.

8. Di Nicola M, Carlo-Stella C, Magni M, Milanesi M, Longoni PD, Matteucci P, et al. Human Bone Marrow Stromal Cells Supress T-Lymphocyte Proliferation Induced by Cellular or Nonspecific Mitogenic Stimuli. Blood 2002; 99: 3838-43.

9. Waterman RS, Tomchuck SL, Henkie SL, Betancourt AM. A New Mesenchymal Stem Cell (MSC) Paradigm: Polarization into a Proinflammatory MSC1 or an Immunosuppressive MSC2 Phenotype. PLoS ONE 2010; 5: e10088.

10. Prockop DJ. Repair of Tissues by Adult Stem/Progenitor Cells (MSC): Controversies, Myths, and Changing Paradigms. Mol Ther 2009; 17: 939-46.

11. Aggarwal S, Pittenger MF. Human Mesenchymal Stem Cells Modulate Allogeneic Immune Cell Response. Blood 2005; 105: 1815-22.

12. Ryan JM, Barry FP, Murphy JM, Mahon BP. Mesenchymal Stem Cells Avoid Allogeneic Rejection. J Inflamm (Lond) 2005; 2: 8.

13. Nakahara H, Dennis JE, Bruder SP, Haynesworth SE, Lennon DP, Caplan Al. In Vitro Differentiation of Bone and Hypertrophic Cartilage from Periosteal-Derived Cells. Exp Cell Res 1991; 195: 492-503.

14. Zuk PA, Zhu M, Mizuno H, De Ugarte DA, Huang J, Mizuno $\mathrm{H}$, et al. Multilineage Cells from Human Adipose Tissue: Implications for Cell-Based Therapies. Tissue Eng 2001; 7 : 211-28.

15. Jankowski RJ, Deasy BM Huard J. Muscle Derived Stem Cells. Gene Therapy 2002; 9: 642-7.

16. Young HE, Steele TA, Bray RA, Hudson J, Floyd JA, Hawkins $\mathrm{K}$, et al. Human Reserve Pluripotent Mesenchymal Stem 
Cells are Present in the Connective Tissues of Skeletal Muscle and Dermis Derived From Fetal, Adult and Geriatric Donors. Anat Rec 2001; 264: 51-62.

17. D'Ippolito G, Schiller PC, Ricordi C, Roos BA, Howard GA. AgeRelated Osteogenic Potential of Mesenchymal Stromal Stem Cells from Human Vertebral Bone Marrow. J Bone Miner Res 1999; 14: 1115-22.

18. Pappa KI, Anagnou NP. Novel Sources of Fetal Stem Cells: Where Do They Fit on the Developmental Continuum ?. Regen Med 2009; 4: 423-33.

19. Pittenger MF, Mackay AM, Beck SC, Jaiswal RK, Douglas R, Mosca JD, et al. Multilineage Potential of Adult Human Mesenchymal Stem Cells. Science 1999; 284: 143-7.

20. Zuk PA, Zhu M, Ashjian P, De Ugarte DA, Huang JI, Mizuno H, et al. Human Adipose Tissue is a Source of Multipotent Stem Cells. Mol Biol Cell 2002; 13: 4279-95.

21. Xu Y, Malladi P, Wagner DR, Longaker MT. Adipose-Derived Mesenchymal Cells as a Potential Cell Source for Skeletal Regeneration. Curr Opin Mol Ther 2005; 7: 300-5.

22. Bieback K, Kern S, Klüter H, Eichler H. Critical Parameters for the Isolation of Mesenchymal Stem Cells from Umbilical Cord Blood. Stem Cells 2004; 22: 625-34.

23. Tsai MS, Lee JL, Chang YJ, Hwang SM. Isolation of Human Multipotent Mesenchymal Stem Cells from SecondTrimester Amniotic Fluid Using a Novel Two-Stage Culture Protocol. Hum Reprod 2004; 19: 1450-6.

24. Tsai MS, Hwang SM, Tsai YL, Cheng FC, Lee JL, Chang YJ. Clonal Amniotic Fluid-Derived Stem Cells Express Characteristics of Both Mesenchymal and Neural Stem Cells. Biol Reprod 2006; 74: 545-51.

25. Zhao $\mathrm{P}$, Ise $\mathrm{H}$, Hongo $\mathrm{M}$, Ota $\mathrm{M}$, Konishi I, Nikaido T. Human Amniotic Mesenchymal Cells Have Some Characteristics of Cardiomyocytes. Transplantation 2005; 79: 528-35.

26. Ochsenbein-Kölble N, Bilic G, Hall H, Huch R, Zimmermann R. Inducing Proliferation of Human Amnion Epithelial and Mesenchymal Cells for Prospective Engineering of Membrane Repair. J Perinat Med 2003; 31: 287-94.

27. In 't Anker PS, Scherjon SA, Kleijburg-van der Keur C, de Groot-Swings GM, Claas FH, Fibbe WE, et al. Isolation of Mesenchymal Stem Cells of Fetal or Maternal Origin from Human Placenta. Stem Cells 2004; 22: 1338-45.

28. Portmann-Lanz CB, Schoeberlein A, Huber A, Sager $R$, Malek A, Holzgreve W. Placental Mesenchymal Stem Cells as Potential Autologous Graft for Pre- and Perinatal Neurogeneration. Am J Obstet Gynecol 2006; 194: 66473.

29. Kim JW, Kim SY, Park SY, Kim YM, Kim JM, Lee MH, et al. Mesenchymal Progenitor Cells in the Human Umbilical Cord. Ann Hematol 2004; 83: 733-8.

30. Fu YS, Cheng YC, Lin MY, Cheng H, Chu PM, Chou SC, et al, Conversion of Human Umbilical Cord Mesenchymal Stem Cells in Wharton's Jelly to Dopaminergic Neurons In Vitro: Potential Therapeutic Application for Parkinsonism. Stem Cells 2006; 24: 115-24.

31. Horwitz EM, Prockop DJ, Fitzpatrick LA, Koo WW, Gordon PL, Neel M, et al. Transplantability and Therapeutic Effects of Bone Marrow-Derived Mesenchymal Cells in Children with Osteogenesis Imperfecta. Nat Med 1999; 5: 309-13.

32. Koc ON, Gerson SL, Cooper BW, Dyhouse SM, Haynesworth $\mathrm{SE}$, Caplan AL, et al. Rapid Hematopoietic Recovery After Coinfusion of Autologous-Blood Stem Cells and Culture-Expanded Marrow Mesenchymal Stem Cells in Advanced Breast Cancer Patients Receiving High-Dose Chemotherapy. J Clin Oncol 2000; 18: 307-16.

33. Mueller SM, Glowacki J. Age-Related Decline in the Osteogenic Potential of Human Bone Marrow Cells Cultured in ThreeDimensional Collagen Sponges. J Cell Biochem 2001; 82: 583-90.
34. Gimble JM, Guilak F. Differentiation Potential of Adipose Derived Adult Stem Cell (ADAS) Cells. Curr Top Dev Biol 2003; 58: 137-60.

35. Wagner W, Wein F, Seckinger A, Frankhauser M, Wirkner $\mathrm{U}$, Krause $\mathrm{U}$, et al. Comparative Characteristics of Mesenchymal Stem Cells from Human Bone Marrow, Adipose Tissue, and Umbilical Cord Blood. Exp Hematol 2005; 33: 1402-16.

36. Kern S, Eichler H, Stoeve J, Kluter H, Bieback K. Comparative Analysis of Mesenchymal Stem Cells from Bone Marrow, Umbilical Cord Blood, or Adipose Tissue. Stem Cells 2006; 24: 1294-301.

37. Halvorsen YD, Franklin D, Bond AL, Hitt DC, Auchter C, Boskey $\mathrm{AL}$, et al. Extracellular Matrix Mineralization and Osteoblast Gene Expression by Human Adipose Tissue-Derived Stromal Cells. Tissue Eng 2001; 7: 729-41.

38. Mizuno H, Zuk PA, Zhu M, Lorenz HP, Benhaim P, Hedrick MH. Myogenic Differentiation by Human Processed Lipoaspirate Cells. Plast Reconstr Surg 2002; 109: 199-209.

39. Safford KM, Hicok KC, Safford SD, Halvorsen Y-DC, Wilkinson WO, Gimble JM, et al. Neurogenic Differentiation of Murine and Human Adipose-Derived Stromal Cells. Biochem Biophys Res Commun 2002; 294: 371-9.

40. Izadpanah R, Trygg C, Patel B, Kriedt C, Dufour J, Gimble JM, et al. Biologic Properties of Mesenchymal Stem Cells Derived from Bone Marrow and Adipose Tissue. J Cell Biochem 2006; 99: 1285-97.

41. Sessarego N, Parodi A, Podesta M, Benvenuto F, Mogni M, Raviolo V, et al. Multipotent Mesenchymal Stromal Cells from Amniotic Fluid: Solid Perspectives for Clinical Application. Haematologica 2008; 93: 339-46.

42. Reinisch A, Bartmann C, Rohde E, Schallmoser K, Bjelic-Radisic V, Lanzer G, et al. Humanized System to Propagate Cord Blood-Derived Multipotent Mesenchymal Stromal Cells for Clinical Application. Regen Med 2007; 2: 371-82.

43. Kita K, Gauglitz GG, Phan TT, Herndon DN, Jeschke MG. Isolation and Characterization of Mesenchymal Stem Cells from the Sub-Amniotic Human Umbilical Cord Lining Membrane. Stem Cells Dev 2010; 19: 491-501.

44. Parolini O,AlvianoF, Bagnara GP, Bilic G, Buhring HJ, Evangelista $M$, et al. Concise Review : Isolation and Characterization of Cells from Human Term Placenta : Outcome of the First International Workshop on Placenta Derived Stem Cells. Stem Cells 2008; 26: 300-11.

45. Karahuseyinoglu S, Cinar O, Kilic E, F Kara, GG Akay, DO Demiralp, et al. Biology of the Stem Cells in Human Umbilical Cord Stroma: In Situ and In Vitro Surveys. Stem Cells 2007; 25: 319-31.

46. Romanov YA, SvintsitskayaVA, Smirnov VN. Searching for Alternative Sources of Postnatal Human Mesenchymal Stem Cells: Candidate MSC-like Cells from Umbilical Cord. Stem Cells 2003; 21: 105-10.

47. Wang HS, Hung SC, Peng ST, Huang CC, Wei HM, Guo YJ, et al. Mesenchymal Stem Cells in the Wharton's jelly of the Human Umbilical Cord. Stem Cells 2004; 22: 1330-7.

48. Sarugaser R, Lickorish D, Baksh D, Hosseini MM, Davies JE. Human Umbilical Cord Perivascular (HUCPV) cells: A Source of Mesenchymal Progenitors. Stem Cells 2005; 23: 220-9.

49. Can A, Karahuseyinoglu S. Concise Review: Human Umbilical Cord Stroma with Regards to the Source of Fetus-Derived Stem Cells. Stem Cells 2007; 25: 2886-95.

50. Hemberger M, Yang W, Natale D, Brown TL, Dunk C, Gargett $\mathrm{CE}$, et al. Stem Cells from Fetal Membranes: A Workshop Report. Placenta. 2008;29 Suppl A:S17-9.

51. DeCoppi P, Bartsch G Jr, Siddiqui MM, Xu T, Santos CC, Perin $\mathrm{L}$, et al. Isolation of Amniotic Stem Cells with Potential for Therapy. Nat Biotechol 2007; 25: 100-6. 
52. Roubelakis MG, Pappa KI, Bitsika V, Zagoura D, Vlahou A, Papadaki HA, et al. Molecular and Proteomic Characterization of Human Mesenchymal Stem Cells Derived From Amniotic Fluid: Comparison to Bone Marrow Mesenchymal Stem Cells. Stem Cells Dev 2007; 16: 93152.

53. Kim J, Lee Y, Kim H, Hwang KJ, Kwon HC, Kim SK, et al. Human Amniotic Fluid-Derived Stem Cells Have Characteristics of Multipotent Stem Cells. Cell Prolif 2007; 40: 75-90.

54. Bossolasco P, Montemurro T, Cova L, Zangrossi S, Calzarossa $\mathrm{C}$, Buiatiotis $\mathrm{S}$, et al. Molecular and Phenotypic Characterization of Human Amniotic Fluid Cells and Their Differentiation Potential. Cell Res 2006; 16: 329-36.

55. Prusa AR, Morton E, Rosner M, Bernaschek G, Hengstschlager M. Oct-4 Expressing Cells in Human Amniotic Fluid: A New Source for Stem Cell Research ?. Hum Reprod 2003; 18: 1489-93.

56. Prusa AR, Marton E, Rosner M, et al. Neurogenic Cells in Human Amniotic Fluid. Am J Obstet Gynecol 2004; 191: 309-14.

57. Perin L, Sedrakyan S, Da Sacco S, De Filippo R. Characterization of Human Amniotic Fluid Stem Cells and Their Pluripotential Capacity. Methods Cell Biol 2008; 86: 85-99,

58. Kolambkar YM, Peister A, Soker S, Atala A, Guldberg RE. Chondrogenic Differentiation of Amniotic Fluid-Deriven Stem Cells. J Mol Histol 2007; 38: 405-13.

59. Kunisaki SM, Armant M, Kao GS, Stevenson K, Kim H, Fauza DO. Tissue Engineering from Human Mesenchymal Amniocytes: A Prelude to Clinical Trials. J Pediatr Surg 2007; 42: 974-80.

60. Hoehn H, Salk D. Morphological and Biochemical Heterogeneity of Amniotic Fluid Cells in Culture. Methods Cell Biol 1982; 26: 11-34.

61. Heidari Z, Isobe K, Goto S, Nakashima I, Kiuchi K, Tomoda Y, Characterization of the Growth Factor Activity of Amniotic Fluid on Cells from Hematopoietic and Lymphoid Organs of Different Life Stages. Microbiol Immunol 1996; 40: 583-9.

62. Srivastava MD, Lippes J, Srivastava BI. Cytokines of the Human Reproductive Tract. Am J Reprod Immunol 1996; 36: 15766.

63. Bartha JL, Romero-Carmona R, Comino-Delgado R, Arce $\mathrm{F}$ Arrabal J. Alpha-Fetoprotein and Hematopoietic Growth Factors in Amniotic Fluid. Obstet Gynecol 2000; 96: 58892.

64. Bili C, Divane A, Apessos A, Konstantinos T, Apostolos A, loannis $\mathrm{B}$, et al. Prenatal Diagnosis of Common Aneuploidies Using Quantitative Fluorescent PCR. Prenat Diagn 2002; 22: $360-5$.

65. Meron PM. Preparation, Culture and Analysis of Amniotic Fluid Samples. Curr Protoc Hum Genet. 2001; Chapter 8: Unit 8.4

66. Kaviani A, Perry TE, Dzakovic A, Jennings RW, Ziegler MM, Fauza DO. The Amniotic Fluid as a Source of Cells for Fetal Tissue Engineering. J Pediatr Surg 2001; 36: 1662-5.

67. Kaviani A, Guleserian K, Perry TE, Jennings RW, Ziegler MM, Fauza DO. Fetal Tissue Engineering From Amniotic Fluid. J Am Coll Surg 2003; 196: 592-7.

68. In't Anker PS, Scherjon SA, Kleijburg-van der Keur C, Noort WA, Claas FH, Willemze R, et al. Amniotic Fluid as a Novel Source of Mesenchymal Stem Cells for Therapeutic Transplantation. Blood 2003; 102: 1548-9.

69. Fehrer C, Lepperdinger G. Mesenchymal Stem Cell Aging. Exp Gerontol 2005; 40: 926-30.

70. Sethe S, Scutt A, Stolzing A. Aging of Mesenchymal Stem Cells. Ageing Res Rev 2006; 5: 91-116.

71. Wagner W, Horn P, Castoldi M, Diehlmann A, Bork S, Saffrich R, et al. Replicative Senescence of Mesenchymal Stem Cells: A Continuous and Organized Process. PLoS One 2008; 3: e2213.
72. Kim J, Kang JW, Park JH, Choi Y, Choi KS, Park KD, et al. Biological Characterization of Long-Term Cultured Human Mesenchymal Stem Cells. Arch Pharm Res 2009; 32: 11726.

73. Chen WQ, Siegel N, Li L, Pollak A, Hengstschlager M, Lubec G. Variations of Protein Levels in Human Amniotic Fluid Stem Cells CD117/2 Over Passages 5-25. J Proteome Res 2009; 8: 5285-95.

74. Miranda-Sayago JM, Fernandez-Arcas N, Benito C, ReyesEngel A, Carrera J, Alonso A. Lifespan of Human Amniotic Fluid-Derived Multipotent Mesenchymal Stromal Cells. Cytotherapy 2011; 13: 572-81.

75. Bollini S, Cheung KK, Riegler J, Dong X, Smart N, Ghionzoli $\mathrm{M}$, et al. Amniotic Fluid Stem Cells are Cardioprotective Following Acute Myocardial Infarction. Stem Cells Dev 2011; 20: 1985-94.

76. Bitsika V, Roubelakis MG, Zagoura, Trohatou O, Makridakis $\mathrm{M}$, Pappa $\mathrm{Kl}$, et al. Human Amniotic Fluid-Derived Mesenchymal Stem Cells as Therapeutic Vehicles : A Novel Approach for the Treatment of Bladder Cancer. Stem Cells Dev 2012; 21: 1097-111.

77. Broxmeyer HE, Srour E, Orschell C, Ingram DA, Cooper S, Plett PA, et al. Cord Blood Stem Cells and Progenitor Cells. Methods Enzymol 2006; 419: 439-73.

78. Tondreau T, Meuleman N, Delforge A, Dejeneffe M, Leroy R, Massy $M$, et al. Mesenchymal Stem Cells Derived From CD133-Positive Cells in Mobilized Peripheral Blood and Cord Blood : Proliferation, Oct-4 Expression and Plasticity. Stem Cells 2005; 23: 1105-12.

79. Greco SJ, Lin K, Rameshwar P. Functional Similarities Among Genes Regulated by Oct4 in Human Mesenchymal and Embryonic Stem Cells. Stem Cells 2007; 25: 3143-54.

80. McGuckin CP, Forraz N, Baradez MO, Navran S, Zhao J, Urban R, et al. Production of Stem Cells with Embryonic Characteristics from Human Umbilical Cord Blood. Cell Prolif 2005; 38: 245-55.

81. Zhao $\mathrm{Y}$, Wang $\mathrm{H}$, Mazzone T. Identification of Stem Cells from Human Umbilical Cord Blood with Embryonic and Hematopoietic Characteristics. Exp Cell Res 2006; 312: 2454-64.

82. Markov V, Kusumi K, Tadesse MG, William DA, Hall DM, Lounev $\mathrm{V}$, et al. Identification of Cord Blood-Derived Mesenchymal Stem/Stromal Cell Populations with Distinct Growth Kinetics, Differentiation Potentials, and Gene Expression Profiles. Stem Cells Dev 2007; 16: 53-73.

83. Sun B, Roh KH, Lee SR, Lee YS, Kang KS. Induction of Human Umbilical Cord Blood-Derived Stem Cells with Embryonic Stem Cell Phenotypes Into Insulin Producing Islet-Like Structures. Biochem Biophys Res Commun 2007; 354: 919-23.

84. Lee OK, Kuo TK, Chen WM, Lee KD, Hsieh SL, Chen TH. Isolation of Multipotent Mesenchymal Stem Cells from Umbilical Cord Blood. Blood 2004; 103: 1669-75.

85. Madlambayan G, Rogers I. Umbilical Cord-Derived Stem Cells for Tissue Therapy: Current and Future Uses. Regen Med 2006; 1 : 777-87.

86. Meyer FA, Laver-Rudich Z, Tanenbaum R. Evidence for a Mechanical Coupling of Glycoprotein in Microfibrils with Collagen Fibrils in Wharton's Jelly. Biochim Biophys Acta 1983; 755: 376-87.

87. Sobolewski K, Bańkowski E, Chyczewski L, Jaworski S. Collagen and Glycosaminoglycans of Wharton's Jelly. Biol Neonate 1997; 71: 11-21.

88. Sakamoto T, Ono H, Saito Y. Electron Microscope Histochemical Studies on the Location of Hyaluronic Acid in Wharton's Jelly of the Human Umbilical Cord. Nippon Sanka Fujinka Gakkai Zasshi 1996; 48: 501-7. 
89. Wang HS, Hung SC, Peng ST, Huang CC, Wei HM, Guo YJ, et al. Mesenchymal Stem Cells in the Wharton's Jelly of the Human Umbilical Cord. Stem Cells 2004; 22: 1330-7.

90. Pereira WC, Khushnooma I, Madkaikar M, Ghosh K. Reproducible Methodology for the Isolation of Mesenchymal Stem Cells from Human Umbilical Cord and Its Potential for Cardiomyocyte Generation. J Tissue Eng Regen Med 2008; 2: 394-9.

91. Lu LL, Liu YJ, Yang SG, Zhao QJ, Wang X, Gong W, et al. Isolation and Characterization of Human Umbilical Cord Mesenchymal Stem Cells with Hematopoiesis-Supportive Function and Other Potentials. Haematologica 2006; 91: 1017-26.

92. Kadam SS, Tiwari S, Bhonde RR. Simultaneous Isolation of Vascular Endothelial Cells and Mesenchymal Stem Cells from the Human Umbilical Cord. In Vitro Cell Dev Biol Anim 2009; 45: 23-7.

93. Nekanti U, Rao VB, Bahirvani AG, Jan M, Totey S, Ta M. LongTerm Expansion and Pluripotent Marker Array Analysis of Wharton's Jelly-Derived Mesenchymal Stem Cells. Stem Cells Dev 2010; 19: 117-30.

94. De Bruyn C, Najar M, Raicevic G, Meuleman N, Pieters K, Stamapoulos B, et al. A Rapid, Simple, and Reproducible Method for the Isolation of Mesenchymal Stromal Cells from Wharton's Jelly Without Enzymatic Treatment. Stem Cells Dev 2011; 20: 547-57.

95. Troyer DL, Weiss ML. Concise Review : Wharton's Jelly-Derived Cells Are a Primitive Stromal Cell Population. Stem Cells 2008; 26: 591-9.

96. Conconi MT, Burra P, Di Liddo R, Calore C, Turetta M, Bellini S, et al. CD105+ cells from Wharton's Jelly Show In Vitro and In Vivo Myogenic Differentiation Potential. Int J Mol Med 2006; 18: 1089-96.

97. Mitchell KE, Weiss ML, Mitchell BM, Martin P, Davis D, Morales $\mathrm{L}$, et al. Matrix Cells from Wharton's Jelly Form Neurons and Glia. Stem Cells 2003; 21: 50-60.

98. Kadner A, Hoerstrup SP, Tracy J, Breymann C, Maurus CF, Melnitchouk S, et al. Human Umbilical Cord Cells: A New Cell Source for Cardiovascular Tissue Engineering. Ann Thorac Surg 2002; 74: S1422-8.

99. Anzalone R, Lo lacono M, Corrao S, Magno F, Loria T, Cappello $\mathrm{F}$, et al. New Emerging Potentials for Human Wharton's Jelly Mesenchymal Stem Cells : Immunological Features and Hepatocyte-Like Differentiative Capacity. Stem Cells Dev 2010; 19: 423-38.

100. Fan CG, Zhang Q, Zhou JR. Therapeutic Potentials of Mesenchymal Stem Cells Derived from Human Umbilical Cord. Stem Cell Rev. 2011; 7: 195-207.

101. Chao KC, Chao KF, Fu YS, Liu SH. Islet-Like Clusters Derived from Mesenchymal Stem Cells in Wharton's Jelly of the Human Umbilical Cord for Transplantation to Control Type I Diabetes. PLoS ONE 2008; 3: e1451.

102. Bailey MM, Wang L, Bode CJ, Mitchell KE, Detamore MS. A Comparison of Human Umbilical Cord Matrix Stem Cells and Temporomandibular Joint Condylar Chondrocytes for Tissue Engineering Temporomandibular Joint Condylar Cartilage. Tissue Eng 2007; 13: 2003-10.

103. Baksh D, Yao R, Tuan RS. Comparison of Proliferative and Multilineage Differentiation Potential of Human Mesenchymal Stem Cells Derived from Umbilical Cord and Bone Marrow. Stem Cells 2007; 25: 1384-92.

104. Naughton BA. Cells Isolated from Wharton's Jelly of the Human Umbilical Cord Develop a Cartilage Phenotype when Treated with TGF- $\beta$ In Vitro. FASEB J 1997; 11: A19 (Abstr No.108).

105. Wang L, Ott L, Seshareddy K, Weiss ML, Detamore MS. Musculoskeletal Tissue Engineering with Human Umbilical Cord Mesenchymal Stromal Cells. Regen Med 2011; 6: 95109.
106. Fu YS, Shih YT, Cheng YC, Min MY. Transformation of Human Umbilical Mesenchymal Cells into Neurons In Vitro. J Biomed Sci 2004; 11: 652-60.

107. Fu YS, Cheng YC, Lin MY, Cheng H, Chu PM, Chou SC, et al. Conversion of Human Umbilical Cord Matrix Stem Cells in Wharton's Jelly to Dopaminergic Neurons In Vitro: Potential Therapeutic Application for Parkinsonism. Stem Cells 2006; 24: 115-24.

108. Lin YC, Ko TL, Shih YH, Anya Lin MY, Fu TW, Hsiao HS, et al. Human Umbilical Mesenchymal Stem Cells Promote Recovery After Ischemic Stroke. Stroke 2011; 42: 2045-53.

109. Tsuji $\mathrm{H}$, Miyoshi S, Ikegami $\mathrm{Y}$, Hida N, Asada $\mathrm{H}$, Togashi I, et al. Xenografted Human Amniotic Membrane_Derived Mesenchymal Stem Cells Are Immunologically Tolerated and Transdifferentiated Into Cardiomyocytes. Circ Res 2010; 106: 1613-23.

110.Marcus AJ, Coyne TM, Rauch J, Woodburry D, Black IB. Isolation, Characterization and Differentiation of Stem Cells Derived from the Rat Amniotic Membrane. Differentiation 2008; 76: 130-44.

111.Alviano F, Fossati V, Marchionni C, Arpinati M, Bonsi L, Franchina $\mathrm{M}$, et al. Term Amniotic Membrane is a High Throughput Source for Multipotent Mesenchymal Stem Cells with the Ability to Differentiate Into Endothelial Cells In Vitro. BMC Dev Biol. 2007; 7: 11.

112.Parolini O, Alviano F, Bergwerf I, Boraschi D, De Bari C, De Waele $\mathrm{P}$, et al. Toward Cell Therapy Using Placenta-Derived Cells : Disease Mechanisms, Cell Biology, Preclinical Studies, and Regulatory Aspects at the Round Table. Stem Cells Dev 2010; 19: 143-54.

113.Miki T, Lehmann T, Cai H, Stolz DB, Strom SC. Stem Cell Characteristics of Amniotic Epithelial Cells. Stem Cells. 2005; 23: 1549-59.

114.Sakuragawa N, Misawa $\mathrm{H}$, Ohsugi $\mathrm{K}$, Kakishita $\mathrm{K}$, Ishii $\mathrm{T}$, Thangavel $\mathrm{R}$, et al. Evidence for Active Acetylcholine Metabolism in Human Amniotic Epithelial Cells : Applicable to Intracerebral Allografting for Neurologic Disease. Neurosci Lett. 1997; 232: 53-6.

115.Elwan MA, Sakuragawa N. Evidence for Synthesis and Release of Catecholamin by Human Amniotic Epithelial Cells. Neuroreport 1997; 8: 3435-8.

116.Sakuragawa N, Thangavel R, Mizuguchi M, Hirasawa M, Kamo I. Expression of Markers for Both Neuronal and Glial Cells in Human Amniotic Epithelial Cells. Neurosci Lett. 1996; 209: 9-12.

117.Kakishita K, Elwan MA, Nakao N, Itakura T, Sakuragawa N. Human Amniotic Epithelial Cells Produce Dopamine and Survive After Implantation Into the Striatum of a Rat Model of Parkinson's Disease: a Potential Source of Donor for Transplantation Therapy. Exp Neurol. 2000; 165: 27-34.

118.Kakishita K, Nakao N, Sakuragawa N, Itakura T. Implantation of Human Amniotic Epithelial Cells Prevents the Degeneration of Nigral Dopamine Neurons in Rats with 6-Hydroxydopamine Lesions. Brain Res. 2003; 980: 48-56.

119.Bankiewicz KS, Palmatier M, Plunkett RJ, Cummins A, Oldfield EH. Reversal of Hemiparkinsonian Syndrome in Nonhuman Primates by Amnion Implantation into Caudate Nucleus. $\mathrm{J}$ Neurosurg. 1994; 81: 869-76.

120. Okawa H, Okuda O, Arai H, Sakuragawa N, Sato K. Amniotic Epithelial Cells Transform Into Neuron-Like Cells In The Ischemic Brain. Neuroreport. 2001; 12: 4003-7.

121. Sankar V, Muthusamy R. Role of Human Amniotic Epithelial Cell Transplantation in Spinal Cord Injury Repair Research. Neuroscience 2003; 118: 11-7.

122. Daley GQ, Hyun I, Lindvall O. Mapping The Road to The Clinical Translation of Stem Cells. Cell Stem Cell 2008; 2: 139140. 